\title{
中部地方の微小地震活動 (1)
}

\section{根尾谷断層周辺の微小地震活動}

\author{
名古屋大学理学部犬山地震観測所 大井田 徹 - 山田㓛夫 \\ 名古屋大学理学部地球科学教室 多田 堯 - 伊藤 潔・杉山公造 \\ 岐阜大学教育学部地学教室 佐々 木嘉三 \\ (昭和 46 年 7 月 11 日受理)
}

\section{Microearthquake Activity in Central Honshu, Japan (Part 1) \\ Seismicity of Microearthquakes in the Vicinity of the Neo Valley Fault \\ Tooru OOIDA and Isao YAMADA \\ Inuyama Seismological Observatory, Faculty of Science, Nagoya University}

Takashi Tada, Kiyoshi Ito and Kozo SugiYama

Department of Earth Sciences, Faculty of Science, Nagoya University

\section{Yoshimi SASAKI}

Department of Earth Sciences, Faculty of Education, Gifu University

(Received July 11, 1971)

In order to study the seismic activity of microearthquakes in the southern part of the Neo Valley fault, an observation was carried out in 1968 from September 27 to November 2. Seven observing stations were set near the four stations of Inuyama Seismological Observatory.

About 400 microearthquakes were recorded during this observation, but about 50 epicenters could be determined. Their magnitudes were less than 2 .

Microearthquakes occurred most frequently in the southwestern side of the fault, especially in the area upheaved by the Nobi earthquake of 1891. On the contrary, very few earthquakes occurred in the northeastern side. The focal depths of these shocks were very shallow.

\section{§1.はじめに}

根尾谷断層周辺の微小地震活動については，すでに極微小地震研究グループによる 1963 年 および 1964 年の観測 [三木等 (1965)，渡辺等（1967)]，岐皁大学による観測 [村松 (1958)] 等があり，興味ある結果が報告されている。これ等によれば，根尾谷断層周辺には多数の微小 地震が発生しており，特に断層の南西側に活動の活発な地域が拡がつて拉り，北東側では活動 度が低い，我々は断層南端に和ける活動を調査する目的で 1968 年 10 月より 11 月にかけ, 約 40 日間の臨時観測を行なつた。

\footnotetext{
* 1969 年 6 月 6 日地震学会で発表
} 

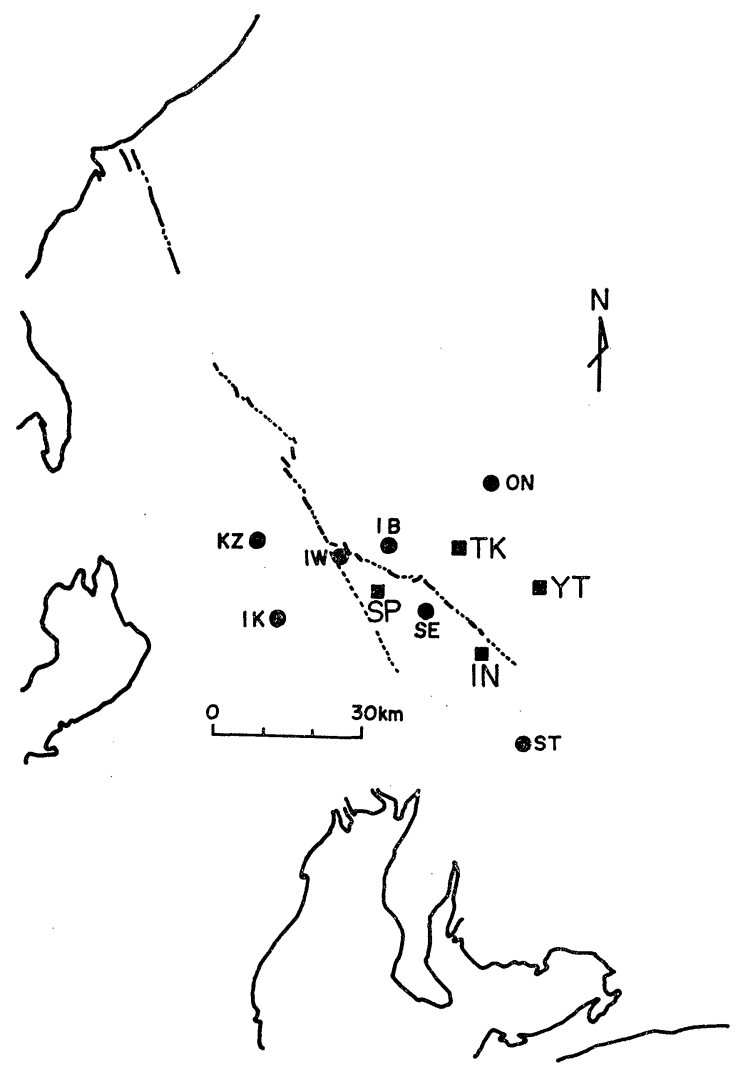

Fig. 1. Observation stations. -.-: fault line at Neo Valley

Table 1. List of temporary and routine stations, Magnifications, recording systems, components and periods of pendulums.

\begin{tabular}{l|c|c|c|c|c}
\hline \multicolumn{1}{c|}{ Station } & Abbr. & Mag. & Recording System & Comp. & Tp \\
\hline Inuyama & IN & $10^{5}$ & Smoked paper & Z, N, E & $1.0(\mathrm{sec})$ \\
Shinpukuji & SP & $10^{5}$ & $\prime \prime$ & Z, N, E & 1.0 \\
Takazawasan & TK & $10^{5}$ & $\prime \prime$ & $Z$ & 1.0 \\
Yaotsu & YT & $5 \times 10^{4}$ & $\prime$ & $Z$ & 0.25 \\
Kuze & KZ & $3 \times 10^{5}$ & Tape recorder & $Z, \mathrm{~N}, \mathrm{E}$ & 1.0 \\
Ikeda & IK & $5 \times 10^{4}$ & Smoked paper & N & 0.25 \\
Iwase & IW & $10^{5}$ & $\prime \prime$ & $Z$ & 1.0 \\
Ibora & IB & $10^{5}$ & $\prime \prime$ & $Z$ & 1.0 \\
Onabi & ON & $10^{5}$ & $\prime \prime$ & $Z$ & 0.25 \\
Sue & SE & $5 \times 10^{4}$ & $\prime \prime$ & $Z$ & 1.0 \\
Seto & ST & $5 \times 10^{4}$ & $\prime \prime$ & $Z(N)$ & 1.0 \\
\hline
\end{tabular}




\section{§ 2. 観測}

根尾谷断層南端部には名古屋大学犬山地震観測所の観測網があるので，これを利用し，他に 7 カ所の臨時観測点を設置した. これらの観測点は $10 \sim 25 \mathrm{~km}$ の間隔で断層の中部から南端 にいたる地域を捺うように配置した。 犬山地震観測所の常設観測網と合わせて 11 力所に地 震計を置いたことになる，観測点の位置を Fig. 1 に示す。また，各観測点の感度，記録方式 等は Table 1 に示しておいた。観測された約 400 個の地震のうらで震源を求めることの できたものは約 50 個，地震の大きさは村松のマグニチュード [村松 $(1964 ， 1966)]$ によれ ばー0.5 2 程度のものである.

\section{§3. 震 源 決 定}

今回の観測では $P$ 波初動を観測する目的で地震計は全ての臨時観測点で上下動速度計を用い た。このため初期微動継続時間 $T_{s-p}$ の不明瞭なものが多かつたので， 3 成分観測を行なつて いた犬山・真福寺・久瀬の着震時 $T_{p}$ と $T_{s-p}$ とから発震時 $T_{0}$ を求め, $P$ 波の伝播速度 $V p$ と均質半無限の地下構造とを仮定し，作図法によつて震源を求めた。今回の観測点を配置 した地域の西部には爆破地震動研究グループの御母衣東方測線 [R.G.E.S. (1961) MIKUMo et al. (1961)]. および花房・倉吉測線 [R. G. E. S. (1966) HASHIZUME et al. 1966)] 等がある.こ れらによれば表層 $2 \sim 3 \mathrm{~km}$ の深さまでは $V_{p}$ の値が $5.5 \mathrm{~km} / \mathrm{sec}$ それ以深では $6.0 \mathrm{~km} / \mathrm{sec}$ となる。 またこの観測期間中に岐阜県本巣郡の石灰岩採石場（観測点伊洞の南西約 $5 \mathrm{~km}$ ）に おいて，かなり大規模な採石発破が数回行なわれ，これらの地震動は数十 $\mathrm{km}$ 離れた犬山，高 沢山等の観測点においても明瞭に観測されている。 Fig. 2 はこれらの採石発破による走時曲

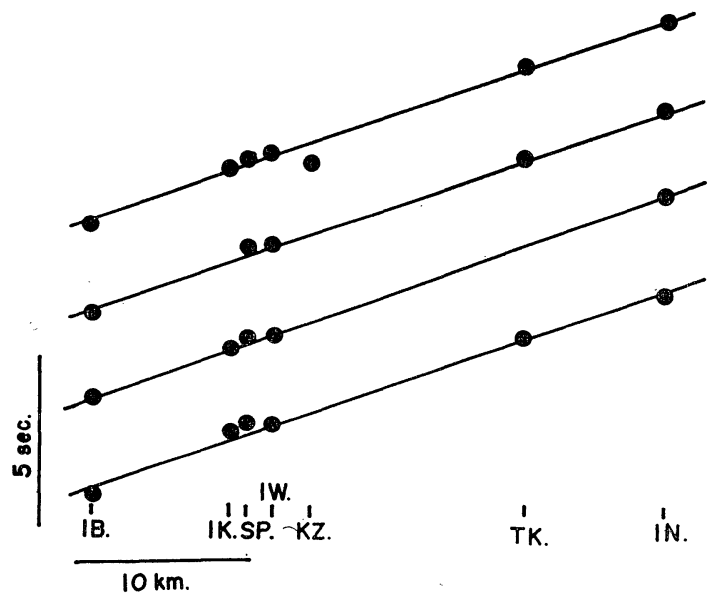

Fig. 2. Travel time curves obtained from quarry explosions. Apparent velocity is $5.65 \mathrm{~km} / \mathrm{sec}$. 

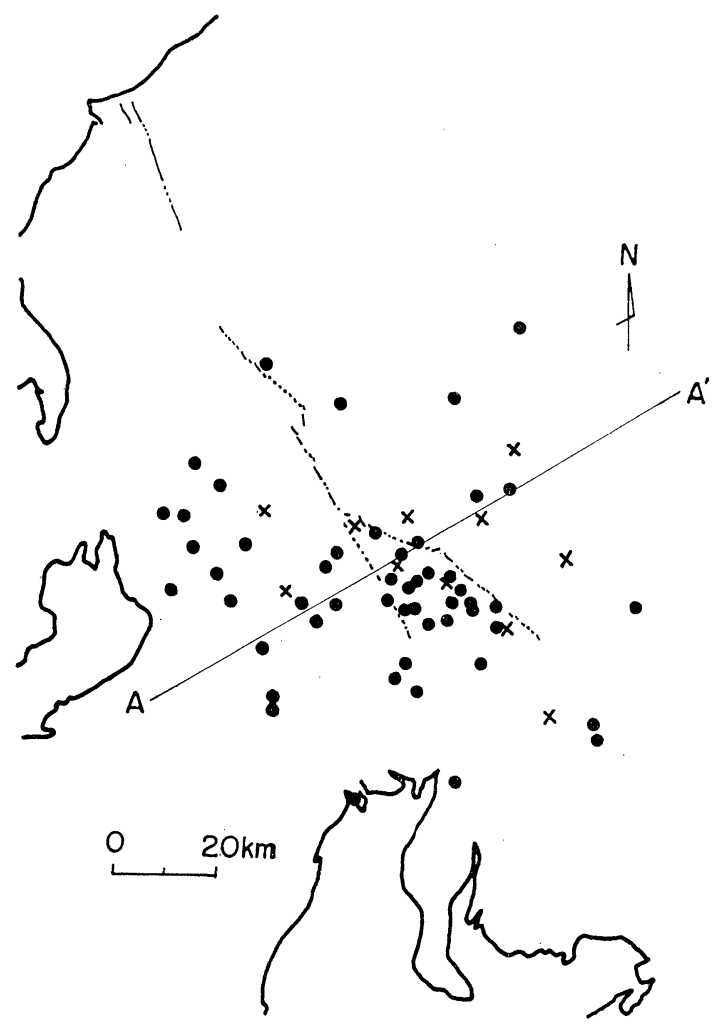

Fig. 3. Distribution of epicenters obtained from the observation in 1968.

๑: epicenter $x$ : observation station -..: Neo Valley fault

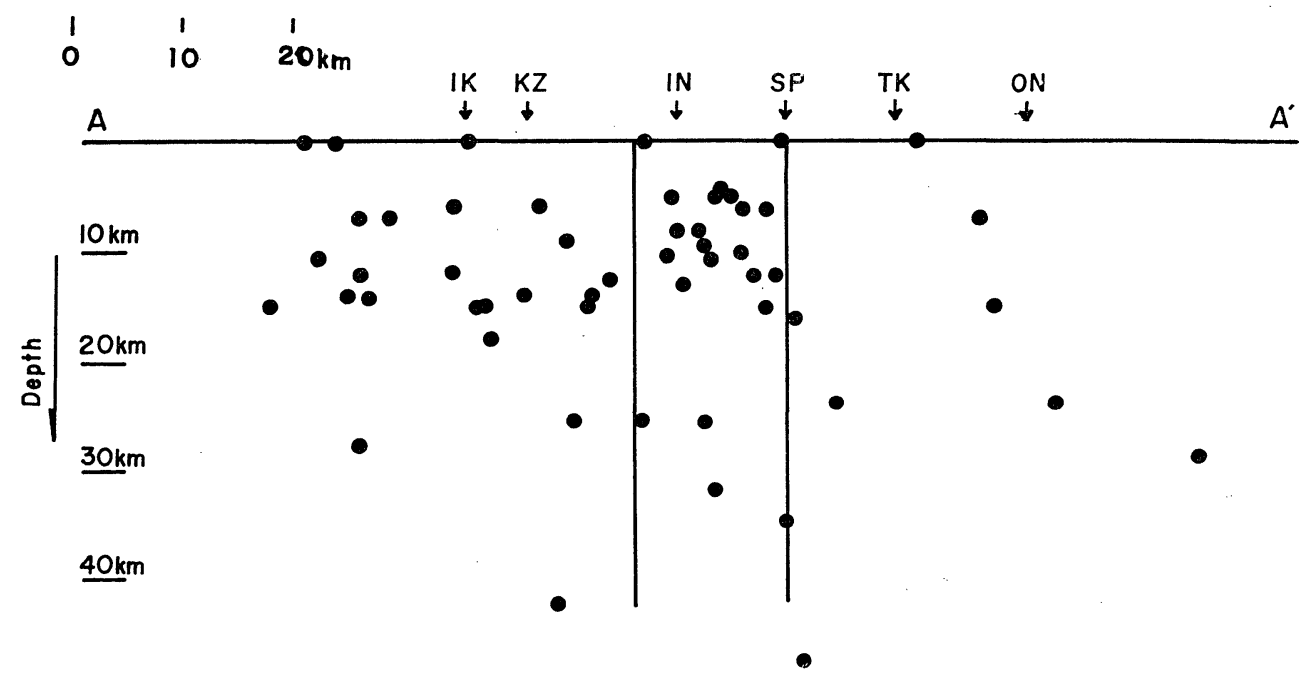

Fig. 4. Hypocenters of earthquakes in Fig. 3, plotted on a vertical section along A-A' line. 
線である.これによれば表層では $V_{p}=5.65 \mathrm{~km} / \mathrm{sec}$ なる值が得られる. 一方，三木等 (1965) によれば根尾谷周辺の 4 観測点以上で観測された地震については $V_{p}=5.6 \mathrm{~km} / \mathrm{sec}$ とした場 合に震源が最もよく求められている，以上のことから $V_{p}=5.6 \mathrm{~km} / \mathrm{sec}$ を採用し，震源を求 めた。

\section{$\S 4$. 震源分布}

求められた震央の分布を Fig. 3 に示した。震央が観測点網から離れ，ぞの観測点での $T_{s-p}$ も 5 秒以上となる地震の震央は省いた。図中の実線拉よび点線は根尾谷断層である. Fig. 4 は これらの断層にほぼ直交する垂直断面に震源を投影した深さによる分布を示す。震源の分布と 断層の位置との間には次のような特徵が見られる，即ち，微小地震は断層の南西側に集中して おこり，北東側ではむしろ散発的である。また，犬山市と岐阜市の北東部を通る断層と西側の 断層との間には特に浅い地震が集中して扣こつている，村松（1963）によれば，この地域は 1891 年の濃尾地震の際に $70 \mathrm{~cm}$ 程度隆起した地域でもあり, この地震の余震等によるものか もしれない.

これらの特徵がたまたま震源決定のできた地震による見掛け上のものかどうかを確かめるた め, 断層の南西側の観測点と北東側の観測点とについての $T_{s-p}$ 頻度分布の比較を行なつてみ
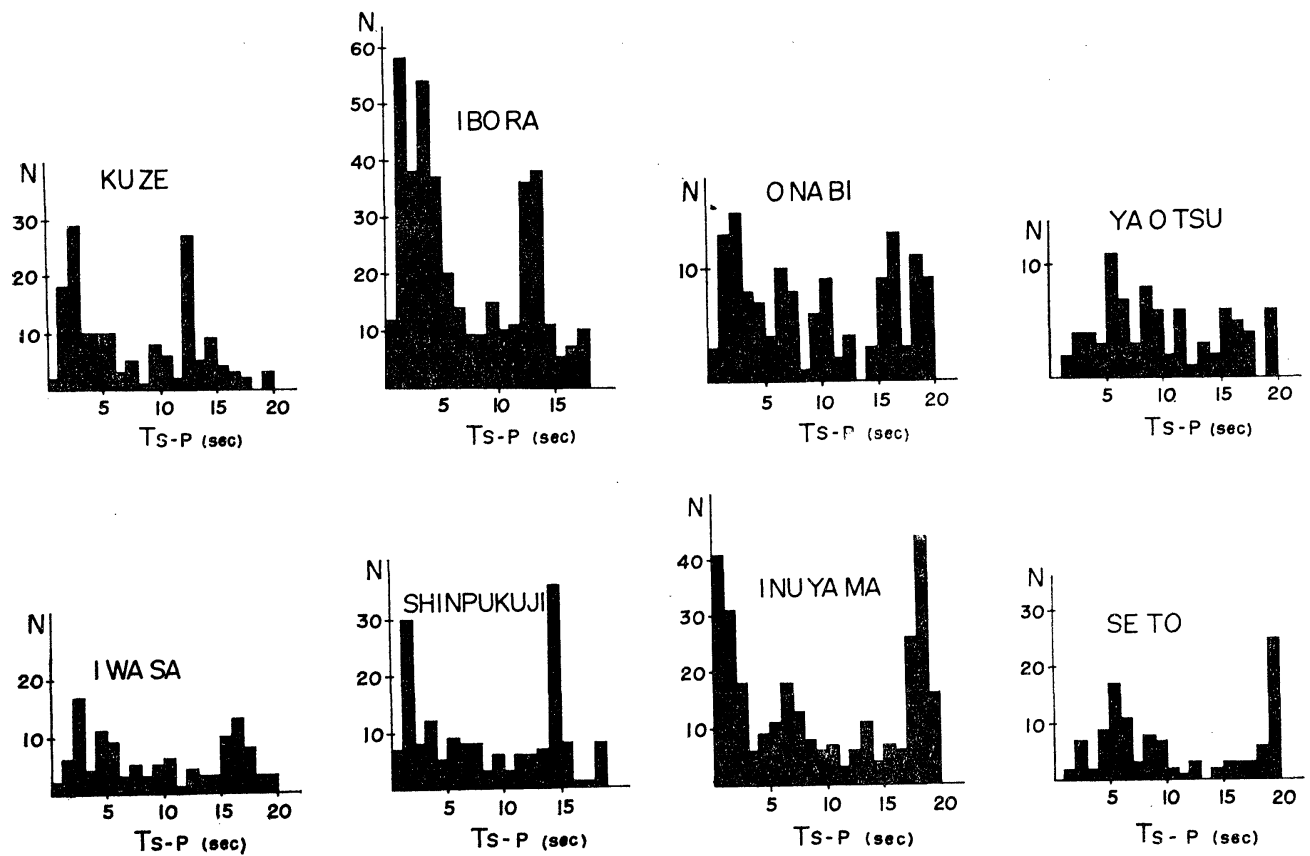

Fig. 5. Distribution of $P-S$ intervals of microearthquakes. 


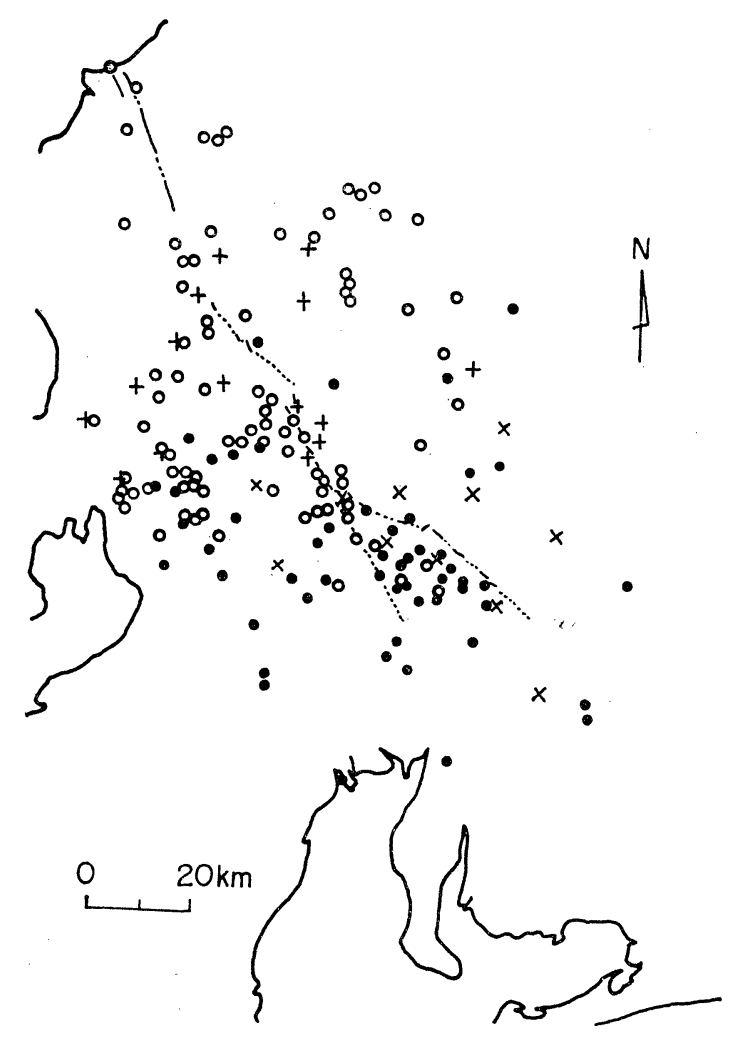

Fig. 6. Distribution of epicenters obtained from observations in 1963, 1964 and 1968. $x$ : observation station in $1968+$ : observation station in 1963 and 1964 : epicenter in $1968 \mathrm{O}$ : epicenter in 1963 and 1964

る. Fig. 5 は各観測点の $T_{s-p}$ 頻度分布である. 地震活動の活発な南西側にある観測点， 久 瀬, 岩佐, 犬山などでは $T_{s-p}$ が 3 秒以下の地震が多いが, 活動の低い北東側の観測点, 八百 津, 小那比等では $T_{s-p}$ が 3 秒以下の地震は少く, 例えば八百津では 1 秒以下の地震は全く観 測されていない。もら一つの特徴は大山地震観測所より南の地域に拉ける微小地震の活動に関 するものである。この地域は今回の観測では観測点が一点しかないのではつきりしたことは不 明であるが，根尾谷断層付近のような浅い地震はほとんど観測されなかつた．根尾谷断層もこ のあたりで終つていてこれより南には続かないよらである。これらの特徵が観測点の配置によ る見掛け上のものかどらか，南側に観測点を設けて観測を行なつたが，その結果については第 2 報で述べる.

Fig. 6 は極微小地震研究グループが観測した根尾谷断層周辺に発生している微小地震の震 央を今回の結果と根尾谷断層で重㸚合わせたものである。（図中×印は今回の観測点, 一印は 


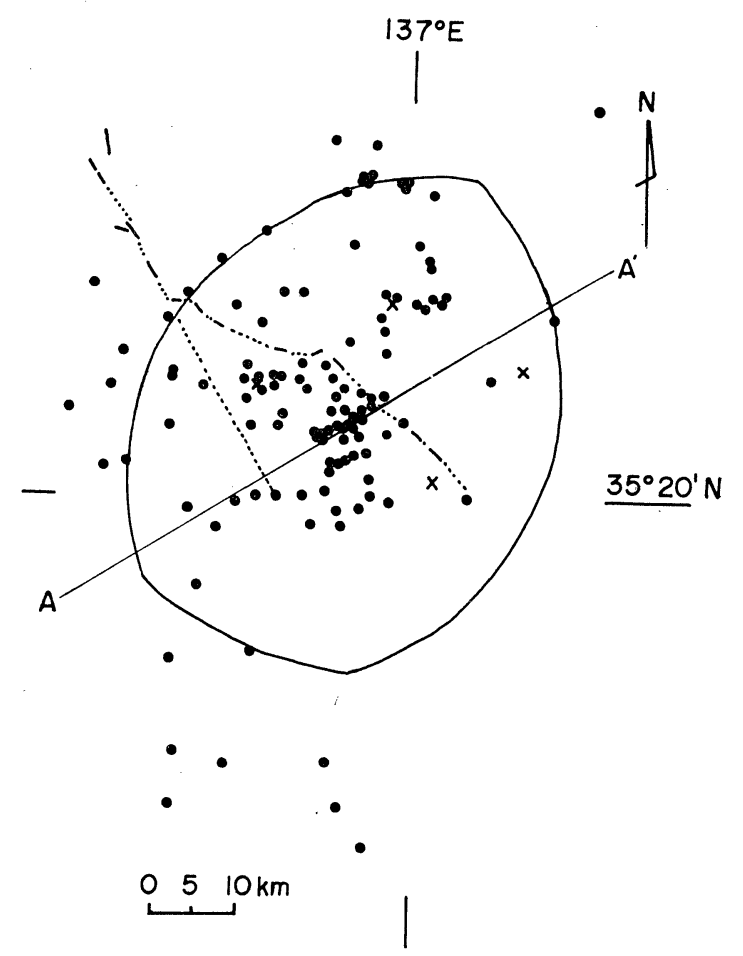

Fig. 7. Distribution of epicenters obtained by four routine stations of Inuyama Seismological Observatory during the period from April, 1968 to January, 1969.

その震央，十印は極微小地震研究グループの観測点，○印はその震央の位置を示す）これらは 観測された時期や期間もはなはだしく異なり，観測方法も異なるので震央を重ね合わせるこ とは問題もあるが，上記の特徵は根尾谷断層全体についてかなり一般的な特徵のように思われ る.またこれらの微小地震の多くは $15 \mathrm{~km}$ 以浅に生じたものである.

\section{§5. 犬山地震観測所常設観測網による震源分布}

犬山地震観測所の観測網は根尾谷断層の南端部に設置され, 常時観測を行なつているので根 尾谷断層南部の微小地震活動を調べるには都合がよい. また今回の観測がこの地域の微小地震 活動の特に異常な時期に行なわれたものかどらかを見る意味でも平常の活動を調べておく必要 がある. 今回の観測の前後, 1968 年 4 月より 1969 年 1 月までの期間に観測された地震のう ち, 各観測点での $T_{p-s}$ が 8 秒以内の地震について震源を求めた。一般に観測網から離れると 震源の精度が悪くなること, また，観測網の中心付近に発生した地震はその規模が小さくても 多くの観測点で観測されやすく, 震源が決定し易いため見掛上震央が観測網の中心付近に集中 
する.これを防ぐためマグニチュード 0 未満の地震を除いた場合の震央を Fig. 7 に示した. 図中にマグニチュード 0 以上の地震が犬山，高沢山，真福寺の 3 観測点で同時に観測される限 界を示した.この分布からも今回と同様の特徵が見られる.

\section{§6. まとめ}

根尾谷断層周辺の臨時観測による微小地震の活動状沉をまとめると次のようになる.

（1）根尾谷断周層辺の微小地震活動はかなり活発である. 特に断層の南西側には多数の微 小地震が起つているが，北東側に起る地震は非常に少ない.

（2）この付近の微小地震は殆んど $15 \mathrm{~km}$ より浅い所で発生しており，25km より深いも のは極めて少ない.

（3）岐阜市から犬山市に至る断層に囲まれた地域（濃尾地震の際最も隆起した地域）には 特に多くの微小地震が発生している.

文献

Hashizume, M., O. Kawamoto, S. Asano, I. Muramatu, T. Asada, I. Tamaki and S. MURAUCHI, 1966, Crustal Structure in the Western Part of Japan Derived from the Observation of the First and Second Kurayosi and the Hanabusa Explosions. Part 2 Crustal Structure in the Western Part of Japan, Bull. Earthq. Res. Inst., 44, 109-120.

三木晴男, 渡辺 晃, 島田充彦, 1965, 根尾谷断層周辺に発生する極微小地震の観測, 地震 2,18 , 103-112.

Mikumo, T., M. Otsuka, T. Utsu, T. Terashima and A. Okada, 1961, Crustal Structure in Central Japan as Derived from the Miboro Explosion-seismic Observations. 2. On the Crustal Structure, Bull. Earthq. Res. Inst., 39, 327-349.

村松有栄, 1958, 岐阜県附近に批る微小地震の観測, 岐阜大学学芸学部研究報告, 2, 157-166.

村松郁栄, 1963, 濃尾地震の被害分布, 岐阜大学学芸学部研究報告, 3, 2, 202-224.

村松郁栄, 1964, Magnitude の定義式について, 地震, 2, 17, 210-221.

村松有栄, 1966, Magnitude の式の訂正抢よび注釈地震, 2, 19, 282-285.

Research Group for Explosion Seismology, 1961, Crustal Structure in Central Japan as Derived from the Miboro Explosion-Seismic Observation. Part 1 Explosion and Seismic Observations. Bull. Earthq. Res. Inst., 39, 285-526.

R. G.E. S., 1966, Crustul Structure in the Western Part of Japan Derived from the Observation of the First and Second Kurayosi and Hanabusa Explosions, 1. Observation of Seismic Waves Generated by the Frist and Second Kurayosi and the Hanabusa Explosions, Bull. Earthq. Res. Inst., 44, 89-107.

渡辺 晃, 中村正夫, 1967, 根尾谷近傍に発生する微小地震の 23 の性質, 地震, 2, 20, 106-115. 